\title{
PENGEMBANGAN MULTIMEDIA PEMBELAJARAN INTERAKTIF ILMU PENGETAHUAN SOSIAL SMP
}

\author{
DEVELOPMENT OF INTERACTIVE MULTIMEDIA LEARNING SOCIAL SCIENCE \\ $S M P$
}

Fidian Dini Arinda

Program Studi Teknologi Pembelajaran,

Pascasarjana Universitas Negeri Malang

email: fidian156@gmail.com

\begin{abstract}
Abstrak: Multimedia Pembelajaran Interaktif Ilmu Pengetahuan Sosial SMP. Karakteristik dari mata pelajaran Ilmu Pengetahuan Sosial kelas VII semester 2 terdiri dari berbagai macam materi yang sifatnya masih abstrak menuntut siswa untuk mengenal lingkungannya sehingga memerlukan visualisasi dalam memahami materinya. Tujuan penelitian pengembangan ini adalah menghasilkan produk media pembelajaran interaktif berdasarkan studi kelayakan dari ahli materi, ahli desain pembelajaran dan ahli media untuk sehingga bisa dimanfaatkan sebagai sumber belajar. Model Pengembangan yang digunakan dalam penelitian ini adalah model Lee Owens. Dari hasil validasi dan uji coba, diperoleh kesimpulan bahwa multimedia pembelajaran interaktif yang dikembangkan dinyatakan valid dan layak digunakan dalam pembelajaran.
\end{abstract}

Kata Kunci: Multimedia Pembelajaran Interaktif, Ilmu Pengetahuan Sosial

\begin{abstract}
Social Studies Interactive Multimedia Learning SMP. Characteristics of social studies class 2nd semester VII consists of various contents that are still abstract requires students to know the environment that need visualization in understanding the content. The purpose of this development research is to produce social studies interactive learning multimedia based on a feasibility study of matter experts, instructional design experts and experts for media that can be used as a learning resource Development model that uses in this research is Lee Owens model. For result validates and test driving, gotten conclusion that Interactive Multimedia Learning Social Science declared for valid and reasonably to uses in learning system
\end{abstract}

Keywords: Interactive Multimedia Learning, Social Studies

Gagne, Briggs dan Wager (1992) mengatakan bahwa pembelajaran adalah suatu kegiatan yang dapat menjadikan peserta didik belajar dan mudah mengetahui apa yang disampaikan oleh guru. Untuk mencapai hal tersebut tentu saja tidak terlepas dari penggunaan media pembelajaran yang merupakan alat untuk menyampaikan pesan. Media merupakan sarana komunikasi kepada siswa yang dapat meningkatkan efektifitas siswa dalam menerima informasi yang disampaikan oleh guru.

Seperti halnya yang terjadi di SMP Plus Fityani Pujon, setelah pengembang melakukan observasi di lapangan pada 5 Desember 2015, diperlukan visualisasi dalam mempelajari materi IPS kelas VII khususnya semester 2 yang berkaitan dengan alur proses. Selain itu karakteristik dari mata pelajaran IPS kelas VII semester 2 terdiri dari berbagai macam materi yang sifatnya masih abstrak menuntut siswa untuk mengenal lingkungannya sehingga memerlukan visualisasi dalam memahami materinya. Pada materi-materi tersebut, ditemukan alur proses dan konsep-konsep yang harus dijelaskan dengan ilustrasi agar siswa dapat mengerti dan memahami konsep yang ditanamkan. Seperti pada materi Kondisi Geografis dan Penduduk Indonesia terdapat konsep letak geografis, astronomis, sosio-kulutural dan geomorfologis. Pada materi Atmosfer membahas tentang sifat fisis atmosfer, lapisan-lapisan atmosfer, unsur unsur pembentuk cuaca. Pada materi Hidrosfer membahas tentang bagaimana proses siklus air, macam perairan darat dan laut.

Sebelumnya guru hanya menggunakan buku paket, atlas dan globe maka visualisasi tidak dapat ditampilkan, sehingga siswa 
mengalami kesulitan belajar. Dengan tidak adanya visualisasi dalam mempelajari materi IPS maka siswa juga akan kesulitan untuk menjelaskan bagaimana proses itu berlangsung dan konsep-konsep tersebut.

Oleh karenanya diperlukan perbaikanperbaikan proses pembelajaran. Salah satu upaya pemecahan masalah belajar itu adalah dengan mengembangkan media pembelajaran yang tepat untuk mengilustrasikan materi yang disampaikan. Salah satu bentuk media pembelajaran yang tepat untuk mengilustrasikan materi yang akan disampaikan adalah dengan menggunakan media pembelajaran berbasis komputer. Berdasarkan uraian di atas memberikan gambaran bahwa permasalahan yang dihadapi dalam proses pembelajaran IPS di SMP Plus Fityani hanya mungkin diatasi jika teknologi pembelajaran diterapkan dalam proses belajar mengajar. Salah satu bentuk teknologi pembelajaran adalah penggunaan media pembelajaran interaktif yang dapat digolongkan ke dalam multimedia.

Kehadiran media pembelajaran interaktif dalam proses belajar mengajar telah membuat suasana yang berbeda dalarn kelas, karena materi yang dulunya diajarkan dengan ceramah dan hanya monoton dapat divariasi dengan menampilkan tayangan berupa integrasi teks, suara, gambar bergerak dan video. Hal ini tentunya akan membuat siswa menjadi tertarik dengan materi yang diajarkan. Sujito (2008) menjelaskan dalarn uji coba lapangan, media interaktif terbukti mampu meningkatkan antusiasme siswa untuk terus belajar.

Dari penjelasan tersebut, maka kehadiran media pembelajaran interaktif di sekolah saat ini merupakan hal yang berguna bagi proses pembelajaran. Pendapat keefektifan penggunaan multimedia interaktif dalam proses pembelajaran di kelas juga dikemukakan oleh Dwiyono (2009) efektifitas pembelajaran terjadi karena siswa dapat melihat berbagai bentuk data baik garnbar, teks, suara, gerak dan peragaan mengenai prosedur pelaksanaan tune up, sehingga memungkinkan siswa lebih menguasai materi pelajaran.
Guru perlu mengembangkan metode yang lebih kreatif dan menggunakan media pembelajaran untuk mendukung penyampaian pelajaran khususnya dalam pengembangan ini pada mata pelajaran IPS. Dalam pengembangan metode pembelajaran tidak akan terlepas dari namanya media. Media kini sudah banyak sekali dijadikan sebagai basis pembelajaran karena terbukti media dapat melengkapi dan mendukung kegiatan interaksi pendidik dalam kegiatan pembelajaran. Lectora inspire merupakan software pengembangan belajar yang relatif mudah diaplikasikan karena tidak memerlukan pemahaman bahasa program yang canggih. Karena Lectora Inspire memiliki antarmuka yang familiar dengan kita yang telah menggunakan office (Mas'ud, 2012)

Pentingnya multimedia dengan menggunakan software Lectora untuk membantu proses pembelajaran, karena pada dasarnya proses pembelajaran adalah proses komunikasi. Proses komunikasi harus diciptakan atau diwujudkan melalui kegiatan penyampaian dan tukar menukar pesan antara guru dan siswa. Pesan atau informasi dapat berupa pengetahuan dapat berupa pengetahuan, keahlian, kemampuan, ide, pengalaman dan sebagainya yang dituangkan dan ditampilkan ataupun disampaikan kepada siswa dengan Lectora Inspire. Penggunaan media berbasis teknologi dalam hal ini pemanfaatan Lectora Inspire dapat membantu guru dalam penyampaian materi pelajarn IPS kelas VII semester 2 .

Berdasarkan latar belakang tersebut, maka pengembang tertarik untuk mengembangkan penelitian dengan judul "Pengembangan Multimedia Pembelajaran Interaktif IPS (Ilmu Pengetahuan Sosial) di SMP Plus Fityani Pujon Malang”. Diharapkan media ini dapat digunakan sebagai media pembelajaran di kelas maupun mandiri. Dalam proses belajar mengajar diharapkan nantinya akan memudahkan siswa untuk memahami hal-hal yang sifatnya abstrak dan memberikan lebih banyak bahan ilustrasi yang lebih sempurna dibandingkan dengan media cetak. Penelitian 
ini berusaha memberikan kontribusi dalam pengembangan media pembelajaran sehingga kualitas pendidikan di Indonesia dapat terus meningkat.

\section{METODE}

Jenis metode pengembangan yang digunakan dalam penelitian ini adalah dengan menggunakan model prosedural, yaitu model Lee Owens, sebagai dasar pengembangan multimedia pembelajaran interaktif untuk pelajaran IPS. Dalam model Lee Owens ada beberapa tahap yaitu tahap analisis dan penilaian, tahap desain, tahap pengembangan dan implementasi, dan tahap evaluasi. Pada penelitian ini hanya dilakukan sampai tahap pengembangan.

Tahap analisis menurut Owens dan Lee (2004) adalah: 1) analisis audiens, 2) analisis teknologi, 3) analisis situasi, 4) analisis tugas, 5) analisis isus, 6) analisis kejadian penting, 7) analisis tujuan, 8) analisis Media, 9) analisis data, 10) analisis biaya.

Setelah analisis dilakukan maka langkah selanjutnya adalah tahap desain (perancangan). Dalam tahap ini pengembang melakukan pembuatan produk yang menghasilkan multimedia interaktif. Langkah-langkah yang dilakukan dalam pengembangan produk ini, terbagi menjadi preproduksi (membuat storyboard), produksi (membuat multimedia interaktif), test dan review (review editorial,fungsi,teknis)

Adapun yang menjadi subyek coba adalah ahli media, ahli desain, ahli materi dan siswa-siswa SMP Plus Fityani dengan desain uji coba perseorangan, kelompok kecil dan lapangan. Teknik pengumpulan data yang digunakan dalam penelitian ini adalah melalui wawancara, angket, observasi. Sedankan teknik analisis data yang digunakan adalah; a) analisis deskriptif kualitatif. Teknik analisis deskriptif kualitatif digunakan untuk mengolah data hasil review ahli materi, ahli desain pembelajaran, ahli media pembelajaran. b) analisis deskriptif kuantitatif. Analisis deskriptif kuantitatif digunakan untuk menyajikan data hasil angket sehingga tercapai kesimpulan penelitian.

\section{PEMBAHASAN}

Dari keseluruhan kegiatan pengembangan ini dihasilkan rangkuman analisa produk pembelajaran sebagai berikut :

Karakteristik dan Analisis Multimedia

\section{Tampilan}

Tampilan dalam mendisain harus menarik secara visual tetapi tidak mengganggu konten yang dimuat dalam multimedia. Sampul atau cover memiliki kedudukan penting dalam suatu produk, yaitu untuk menarik perhatian dan juga menggambarkan isi dari suatu media yang diwakilinya. Sehingga desain cover disesuaikan dengan audiens yang menjadi target pengguna media tersebut.

Bagian depan sampul bertuliskan judul media " Multimedia Pembelajaran Interaktif IPS kelas VII semester 2. Pemilihan warna sampul disesuaiakan dengan audiens yang menjadi target dari multimedia interaktif. Warna sampul didominasi warna hijau,

\section{Interaksi}

Pada multimedia ini pengguna (user) dilibatkan untuk berinteraksi dengan program aplikasi. Pengguna dapat memindahkan atau menggeser objek tertentu dengan menggunakan mouse. Multimedia ini memberikan pertanyaan-pertanyaan dalam urutan yang diinginkan secara otomatis, memberikan pujian untuk jawaban yang benar, memberikan informasi tentang jawaban yang salah, dan siswa memiliki lebih dari satu kesempatan untuk menjawab pertanyaan. Seperti pada pada layout "matching pair", layout "drag n drop", dan game yang memberikan feedback bagi penggunanya

\section{Kontrol}

Agar dapat memahami multimedia yang di desain maka perlu ada menu dipakai sebagai sajian dalam web tersebut, panel dipakai untuk memajumundurkan halaman, help untuk menolong apabila pengguna tentang tombol tertentu. 


\section{Susunan}

Dalam desain multimedia ini perlu menyusun materi atau konten dengan baik agar siswa dapat memahami dan mengikuti apa yang disajikan dalam multimedia tersebut. Multimedia interaktif ini menyajikan tiga pokok bahasan IPS kelas VII semester II, permainan edukatif dalam bentuk teks, dan video pengetahuan yang diambil dari youtube.

\section{Teks}

Dalam produk multimedia yang dikembangkan tidak lepas dari peran teks sebagai salah satu media yang dimanfaatkan untuk menyampaikan pesan. Jenis teks yang digunakan dalam multimedia interaktif pengembangan ini adalah Segoe Ui, Segoe Ui Light, dan Segoe Ui Semibold.

\section{Audio}

Penggunaan audio dalam multimedia interaktif yang dikembangkan secara umum terbagi dua jenis. Yaitu berupa musik serta spesial efek dan audio berupa narasi. Audio musik dan spesial efek digunakan untuk menciptakan lingkungan belajar yang menyenangkan serta menarik perhatian pengguna. Sedangkan narasi digunakan dalam menyampaikan pesan pada setiap materi yang diberikan.

\section{Visual atau Gambar}

Visual atau gambar untuk menyajikan informasi sehingga memudahkan informasi tersebut dicerna. Pemanfaatan visual atau gambar mampu mengkongkritkan sesuatu yang abstrak atau sesuatu yang sulit untuk dipahami bila hanya menggunakan bahasa verbal. Dengan mengintegrasikan komponen visual dalam multimedia interaktif maka pebelajar akan lebih mudah dalam memahami materi.

\section{Video}

Video merupakan media yang sangat unik sebagai penyalur pesan. Media jenis ini mampu memaparkan suatu proses atau prosedur sehingga memudahkan pebelajar dalam memahami materi yang bersifat proses. Kemampuan tersebut dapat dimanfaatkan untuk bentuk pembelajaran yang menggunakan metode tutorial. Selain itu nilai estetika yang dimiliki oleh media video akan menimbulkan daya tarik bagi siswa.

\section{Kepingan CD}

Produk hasil pengembangan ini merupakan multimedia interaktif yang dikemas dalam bentuk kepingan CD. Ukuran produk hasil pengembangan yang relatif kecil yaitu 118 MB dapat disimpan dalam satu keping $C D$ yang biasanya memiliki daya tampung 700MB. Tujuan pengemasan produk dalam bentuk kepingan CD agar produk mudah dibawa dan ekonomis, sehingga produk multimedia interaktif dapat dimainkan pada komputer dimana saja.

\section{Petunjuk pemanfaatan media}

Petunjuk pemanfaatan media disusun dengan maksud untuk membantu tata cara atau langkah-langkah dalam pengoperasian multimedia pembelajaran interaktif ini. Adapun susunan yang terkandung dalam petunjuk pemanfaatan media adalah; a) Identifikasi Produk,b) Kompetensi, c) Petunjuk Penggunaan Media

\section{Kelebihan dan Kekurangan Produk}

Adapun kelebihan produk ini adalah 1)Produk multimedia interaktif yang dikembangkan dapat digunakan sebagai sumber atau bahan ajardalam mata pelajaran IPS kelas VII semester 2, 2)Produk multimedia interaktif dikembangkan berbasiskan komputer, dimana hal ini didasarkan pada minat siswa sebagai pengguna terhadap komputer cukup tinggi, 3)Produk multimedia interaktif hasil pengembangan merupakan gabungan beberapa media ( teks, audio, visual/gambar, video) mampu menciptakan lingkungan belajar yang menarik dan tidak membosankan, 4) Pemanfaatan video, game, yang dintegrasikan dalam multimedia interaktif yang berisiskan penjelasan materi berupa narasi dan animasi memungkinkan mahasiswa untuk dapat belajar mandiri.

Adapun kekurangan dari media ini adalah ; 1)Pembahasan dalam multimedia ini terbatas pada materi Kondisi Geografis dan Penduduk Indonesia, Atmosfer dan Hidrosfer, 2)Dalam pengembangannya, analisis hanya dilakukan terhadap kebutuhan dan karakteristik siswa SMP Fityani Plus, 
sehingga produk multimedia ini hanya cocok digunakan untuk siswa SMP Plus Fityani.

\section{HASIL}

Berdasarkan sajian data diatas, dapat dianalisis bangaimana tingkat kevalidan pada uji ahli media, ahli desain, dan ahli materi sangat valid/ layak. Ditinjau dari tanggapan para ahli multimedia ini menarik untuk diterapkan. Multimedia pembelajaran interaktif IPS kelas VII semester 2 secara keseluruhan, sangat membantu guru dalam menjelaskan pelajaran IPS selain itu siswa juga terlihat antusias dalam mengikuti pelajaran IPS. Setelah uji coba para ahli didapatkan persentase kevalidan multimedia pembelajaran interaktif sebagai berikut ahli media $95 \%$, ahli desain sebesar $85 \%$, ahli materi sebesar 93\%. Sedangkan ujicoba perseorangan sebesar $87,5 \%$, uji kelompok kecil $85 \%$ dan uji kelompok besar $88 \%$

\section{SIMPULAN DAN SARAN}

Dari hasil validasi dan uji coba, diperoleh kesimpulan bahwa multimedia pembelajaran interaktif IPS yang dikembangkan dinyatakan valid dan layak digunakan.

Saran pemanfaatan media ini dapat digunakan secara maksimal untuk pemanfaatan media yang dikembangkan. Saran pemanfaatan ini ditujukan untuk: 1) kepada sekolah diharapkan menjadi masukan menambah media lainnya sehingga dapat membantu pembelajaran, 2) Guru dalam pemanfaatan media ini terlebih dahulu guru harus memahami betul petunjuk pemanfaatan media dan cara pengoperasiannya, 3) Siswa harus mencermati setiap penjelasan yang diberikan oleh guru, 4) Pengembang selanjutnya hendak lebih selektif dalam pemilihan komposisi gambar, deain background, susunan tombol navigasi dan karakteristik tulisan (teks).

Pengembang juga memberikan saran untuk pengembangan produk lebih lanjut antara lain: 1) Multimedia pembelajaran interaktif dikembangkan lebih lanjut dengan memberikan fitur tambahan seperti animasi dan gambar yang lebih menarik sebagai pendukung materi yang diajarkan, 2) Penggunaan jenis dan ukuran teks disesuaikan dengan karakteristik siswa serat dipertimbangkan juga jenis dan ukuran huruf apabila ditinjau dari jarak pengoperasian media, 3) Pengembangan Multimedia pembelajaran interaktif dikembangkan dengan semua materi IPS yang diajarkan di SMP kelas VII selama satu semester.

\section{DAFTAR PUSTAKA}

Dwiyono. 2009. Pengembangan Multimedia Pembelajaran Interaktif Mata Pelajaran Fiqih Untuk Meningkatkan Hasil Belajar Siswa. Tesis. Bandung: UPI.

Gagne, Robert. M , Leslie. J Briggs and Waster W Wager. (1992). Principles of Instructional Design. New York: Harcout Brace Jovanovich College Publisher.

Muhammad Mas'ud. 2012. Membuat Multimedia Pembelajaran dengan Yogyakarta: Pustaka Shonif

Sujito. 2008. Alternatif Pengajaran Sistem Periodik Unsur Menggunakan MediaKomputer Untuk Meningkatkan Keterampilan Berfikir Kreatif Siswa. Tesis. Bandung: UPI 